\title{
The Golden Triangle is in the Papers
}

Hans Steinmüller

Han, Enze. 2019. Asymmetrical Neighbors. Borderland State Building between China and Southeast Asia. Oxford: Oxford University Press, xiii +240 pp.

Brenner, David. 2019. Rebel Politics: A Political Sociology of Armed Struggle in Myanmar's Borderlands. Ithaca: Cornell University Press, 146 pp.

In History and Class Consciousness, Georg Lukács wrote that the impact of commodification on human consciousness can be seen most clearly in journalism. He argues that not just the act of writing, but also the gathering of information, even the perception of the world itself, are governed by the commodity principle: only those pieces of experience that can be packaged and sold as information are processed. As the mind of the journalist gets used to filtering out information that can't be exchanged, commodification changes subjectivity and reduces thought into abstract mechanisms:

... divorced both from the personality of their 'owner' and from the material and concrete nature of the subject matter in hand. The journalist's 'lack of convictions', the prostitution of his experiences and beliefs is comprehensible only as the apogee of capitalist reification" (Lukács 1971, 100).

Lukács possibly exaggerates the monolithic power of commodification (to be overcome by the proletariat, the only group that he believed can see beyond it). But his insight - that journalists rationalize and formalize knowledge, and are incapable of reflecting on the process of reification - is still useful today. It applies to a large part of academic scholarship, specifically in political science, what I call "newspaper science." Using similarly light data and conventional folk theories, newspaper science experiences the same constraints that Lukács identified in journalism: it cannot reflect upon its own conditions of possibility, that is, the formalization and reification of knowledge which make it possible. Journalists can write about journalism itself, but only as long as it sells.

The highlands of the Southeast Asian mainland, and specifically the border area of the Golden Triangle, where China, Myanmar, and Thailand meet, are known to the Englishspeaking world mostly through articles and books written by journalists. Many accounts focus on the history of war and drugs in this region, which in the 1980s was the largest producer of opium and heroin in the world. Wars and drugs are intimately tied to the relative weakness of nation-state governments. Local militias, marooned battalions of the Chinese Nationalist Army (KMT), and communist guerrillas supported by post-1949 China created the fundamentals of nation-state organization in the region, while in Myanmar they contributed to a number of on-going ethnic insurgencies. In contrast, local populations in China and Thailand have been tightly integrated into the respective nation-state administrations.

What explains the various trajectories of nation-states, armed movements, and civil war in this region since WWII? The journalist's answer is a list of factual information, packaged in terms such as "nations," "insurgency," and "drug economies." These terms are used colloquially; given the main purpose is to tell an interesting story that sells, a journalist cannot engage in academic discussions regarding their definitions and the processes of formalization and reification that make these terms theoretical concepts have to be ignored. 
However, the same conceptual questions - What is a state? What is a nation? What is an economy? - are central to the comparative study of politics. They are particularly urgent for anyone seeking a systematic understanding of the histories and societies of highland Southeast Asia, as well as of governance in the region in the absence of nation-state administration.

Newspaper science can provide valuable source material to think about these questions. But as long as its field material and theoretical notions remain essentially journalistic, it cannot address questions of definition and thus cannot produce theoretical concepts for further comparison. Instead, the theory suggested is the reified knowledge that results from processes of formalization and rationalization that are outside the purview of newspaper science itself and yet indispensable for its normal scientific practice.

The dilemmas of such scientific practice are clearly seen in two recent books that deal with state-building and rebel politics in the borderlands of China, Myanmar, and Thailand. In Asymmetrical Neighbours Enze Han promises an exploration of state- and nation-building in the region, but in the main, provides brief and idiosyncratic stories of Yunnan province, the Shan States in Myanmar, and Northern Thailand, from the Tai principalities of the past to the border trade of today. Different chapters deal with the KMT invasion of the Shan States following the end of the Chinese civil war, communist guerrillas in the 1960s, ethnonationalist movements at the border since then, and ceasefire capitalism today. While his subtitle announces an enquiry into state building "between China and Southeast Asia," Han's focus is on the Shan States of Myanmar, where he identifies a "neighbourhood effect" that has to do with Chinese meddling and economic influence.

Asymmetrical Neighbors never rises above the narrow confines of newspaper science. Han relies on pre-filtered sources such as newspapers, archives, and government announcements as the core material for a theory of state-building. As for the international relations branch of newspaper science, this can be easily recognized in the numerous meanings the capitals of current nation-states acquire: "Beijing," for instance, can refer to the Qing Empire, the People's Republic of China, the central government of the latter, or all of China's people. Core terms, such as "state-building," "state capacity," "nation-building," even "international relations", are used both colloquially and theoretically in the same way.

The author never defines these crucial concepts more than "broadly" (footnote 42, p. 172) and "coarsely" (p. 32). What this means is that core definitions are simply adopted from those used by journalists and World Bank economists. Combined into a theory, this looks like the diagrams provided in chapter one (tables 2.3 and 2.4). Only very slightly simplified and adapted, we have the following "theories of neighbourhood effect of state building dynamics as dyads" (p. 32):

\begin{tabular}{l|l|l} 
& asymmetrical & parity \\
\hline adversarial & $(1)$ meddling & (3) confrontation \\
\hline amicable & (2) economic influence & (4) no neighbourhood effect
\end{tabular}

In this diagram, the independent variable is the balance of "power capabilities" between two states (asymmetrical power or parity of power), and the conditional variable is the relationship of the same states (adversarial or amicable). Basically, the diagram contains four syllogisms: If state $\mathrm{A}$ is more powerful than state $\mathrm{B}$, and their relations are adversarial, then this will lead to meddling of A (1). If their relations are amicable, however, then we'll 
have economic influence (2). If there is parity of power, and adversarial relations, then there will be confrontation (3), and if there is parity and amicable relations, then there will be no neighbourhood effect (4). The relative imprecision of the conditional variables, specifically the terms "adversarial" and "amicable," is crucial; only if they are left this imprecise yet reified into concepts that are separated from their subject matter can Han claim a correlation and a possible "neighbourhood effect." The result is that the historical effects of these terms (such as "meddling" or "economic influence") are given in the terms themselves. Take the Shan State of Myanmar as an example. The relationship between what Han calls the "power capabilities" of China and Myanmar today is certainly asymmetrical. If we assume that the balance of power capabilities has been asymmetrical in this way since the consolidation of the People's Republic of China in the 1950s, the relationships between the governments of Myanmar and China have shifted since from adversarial to amicable and back various times. Relations were adversarial during the 1960s and 1970s and have become more amicable since. Correspondingly, one could argue that the neighbourhood effect of Chinese influence on state-building in Myanmar has changed from meddling to economic influence. But reality is not that simple: economic influence on Myanmar by China existed in the past, and meddling continues now. The only way to maintain Han's theory of neighbourhood effect on state-building is by essentializing state relations into plus or minus, and by separating these from existing social realities.

The same is true even for the independent variables in the equation, that is, asymmetrical power capabilities and parity of power capabilities. Broadly defined, the power capabilities of the Chinese government are surely higher than those of the Myanmar government. But this holds true only as long other factors and elements that lie outside the purview of the theory are ignored, such as the underground drug, mining, and gambling economies in the Golden Triangle, for instance. Or the diplomatic efforts of local governments, insurgents, and businesses in the border region, which pretend there are relations of parity between different states and sub-state entities.

Whatever readers might be able to learn about state building here is outside the diagram, that is: it lies in the definitions of states, their powers and their relationships. Simply adopting, broadly and coarsely, the definitions of others thus evades the conceptual work required for the advancement of theory. Consequently, the theoretical propositions that I have summarised here are only stated in chapter one of the book; they have little to no explanatory value in relationship to the empirical material presented in the remaining chapters. The author seems to admit as much when he omits any mention of his neighbourhood effect theory in the conclusion of the same book.

These limitations notwithstanding, readers might want to know how modern states emerged in this border region. Perhaps in this history, there is something that can be learned about the particular workings of governance, maybe even about state- and nation-building? But in his review of local history, Han also remains within the constraints of newspaper science. Six chapters provide a history of the border area of China, Myanmar, and Thailand. But this is based on quotes from newspapers, archives, government spokespersons, and scholars, all of which are listed, summarized, and sometimes judged, but never questioned. Each chapter begins with a short anecdote about the author meeting someone. So, in one chapter, Han crosses the China-Myanmar border at Laiza; in another he meets a Chinese man in Bangkok; in a third he crosses from Mae Sai to Tachileik. Then we have three sections, on China, Myanmar, and Thailand respectively, and finally a one-paragraph conclusion entitled 'concluding remarks.' What is presented in the main sections is a lot of valuable information on state- and nation-building, the tone is factual and narrative, so that core theoretical terms (most importantly "state" and "nation") are never questioned. Chapter seven, for instance, provides three quick surveys of modern nationalism in China, Myanmar, and Thailand, 
followed by summaries of changing ethnic policies in the border region. Han concludes this way:

Each state's version of national identity has different degrees of inclusiveness versus exclusiveness, partly predetermined by the historical processes of political contestation in the post-WWII period. However, such different versions of national belonging and the international politics of cross-border relations have demonstrated how deeply interrelated the nation-building projects have been in these three countries (p. 136).

As such, then, Asymmetrical Neighbors is typical newspaper science. It bears the marks of a rushed publication, each chapter compressed into a standard format, with large chunks of text that simply paraphrase newspaper articles, books by journalists, and the statements of government spokespersons. All this is held together by theoretical propositions that are at once vague and reified, such as, "if one state is more powerful than a neighbouring state, and their relations are adversarial, then this will have a negative effect on the state building of the weaker neighbour" (that is, syllogism one in the diagram above). This is not to say that there is no value in measuring state capacity by "tax revenue as a percentage of GDP" (21) or nation-building by school enrolment and the existence of ethnonationalist movements (26). But such data, even when all the factual history of Tai principalities, KMT movements, communist guerrillas, and ceasefire capitalism is added, does not constitute an explanation of state- or nation-building: The book is no less a useful digest of factual information. And as such, it will be a welcome resource for anyone interested in the region. ${ }^{1}$

Another book that came out last year offers a more systematic understanding of governance in the region. David Brenner's Rebel Politics is very different in ambition and scope, and it is anything but newspaper science: both the empirical basis and the conceptual superstructure clearly distinguish the book from a journalistic account. The author has done several months of fieldwork among Kachin and Karen armed groups in Myanmar. Located to the north and to the south, respectively, of the Golden Triangle, both groups share similar trajectories of confrontation with and adaptation to Myanmar's national government and army. Analysing their respective trajectories, Brenner constructs "a political sociology of armed struggle in Myanmar's borderland" (the subtitle of his book); the building blocks of this political sociology are well crafted and put together into a compelling analytical framework. The core theoretical notion of this framework, however - what he calls the "social contract" between elites and followers - runs similar risks as those that we have identified in the journalistic accounts of the Golden Triangle: namely, the risk of diminishing theoretical acuity for the sake of expedience and persuasion. The "social contract" (and adjacent notions such as the "rebel public sphere" and an "emergent civil society") might be persuasive - but only as long as the author does not address the conditions that make a contractual understanding of sovereignty possible, both in theory and in history.

Brenner's book is brief, succinct, and well-structured. He explains the rise and fall of particular leaders, factional struggles, and the economics of rebel governance in relationship to the "social process" of armed movements; that is, the history and patterns of social relations within movements and between movements and local populations. He brings together an analysis of ceasefire economies, internal contestations, and the external relations

\footnotetext{
${ }^{1}$ Those who are interested in further detail and illustrative material might want to consult the articles, reports, and books by Bertil Lintner, for instance, the definitive history of the Communist Party of Burma (1990), the more comprehensive Burma in Revolt (1999), or the more captivating Merchants of Madness (Lintner and Black 2009).
} 
of ethnic armed groups in Myanmar. This is a refreshingly new approach in the context of Myanmar studies and sets new agendas in the sociology of Myanmar's armed movements. Consequently, the book is bound to become an importance text in the field of conflict and peace studies.

The core argument is deceptively simple: the roots of authority within armed movements lie in the exchange relations and the forms of recognition that emerge between elites and grassroots followers. If such exchange relations are perceived as just and fair, and if followers can recognise themselves in the movement, then authority is stable and legitimate. If exchange relations deteriorate, leaders are perceived as corrupt, and followers distance themselves, and the movement loses legitimacy.

Brenner uses this framework to describe two ethnic armed organizations in Myanmar, the Kachin Independence Organization (KIO) and the Karen National Union (KNU). Specifically, he aims to explain why the KNU leadership signed a ceasefire agreement with the Burmese government in January 2012, just a few months after the long-standing ceasefire between the KIO and the government had ended in the summer of 2011. Both movements share a similar history: they started off in remote mountain regions where they were deeply connected with local populations. In their respective golden age, an informal social contract ruled, exchange relations were balanced and fair, and both soldiers and villagers felt recognised as members of the same rebel movement. In the late 1990s, however, the elites of the movements allowed in outsiders, and gave them concessions for mining and other natural resources. Over the years, dissatisfaction grew among the grassroots, who started to see the old leaders as corrupt sell-outs. Recently, younger groups emerged that re-connect with the grassroots, rejuvenate the organization, and oppose the old guard. The authority of either group depends on the exchange relations they establish according to an (informal) social contract, and the kind of recognition they facilitate in the public sphere of rebel politics. In the case of the KNU, the old guard was still in control in 2011, and therefore ceasefire negotiations were possible, whereas in the KIO, the younger factions had taken the upper hand: and these younger factions created a 'new momentum of rebel political culture' and led the KIO into open battle.

Brenner concludes that the politics of rival rebel factions are based on different exchange relations between rebels and local communities. These politics can take four different forms: co-optation, group fragmentation, contention over authority, or renewed resistance. Aside from exchange relations, ceasefire dynamics within particular movements depend on the recognition and identification of the grassroots with the movement: that is, whether or not a movement is embedded within communities. In the last few pages of the book, the author spells out the policy implications of his analysis: a counterinsurgency approach that aims at eroding rebel authority might be counter-productive for peace, and economic development is no panacea for civil wars.

Brenner's theoretical approach centres on the notion of an informal social contract, which implies a transactional and rationalist understanding of social action. He references the relational sociology of Norbert Elias and Pierre Bourdieu, but the conditions under which social relations can turn into a "rebel figuration" (16), a "public sphere" (27), or even "civil society organizations" (47) are only alluded to in passing. The contractual understanding of a "rebel public sphere" severely limits the comparative validity of this approach to movements characterized by lively public spheres and active civil society organizations, - and thus excludes a large part of what might otherwise be called "rebel politics" in Myanmar and elsewhere.

Even if readers accept that the social contract and public sphere accurately describe the social realities of the Kachin and Karen movements, how did this modern public emerge? Since when is it possible that people can negotiate contracts with political movements? 
Brenner briefly recounts the historical changes championed by colonial administrations, Christian missions, and local elites; but barely touches on how the same changes led to the creation of modern publics. The new languages and media forms that created the same publics, and thus were the precondition of a social contract embracing large self-identifying ethnic groups, are not mentioned at all. In particular, the creation of standardized Kachin and Karen, and the circulation of printed texts among Kachin and Karen communities, played important roles in these respects. What exactly was the nature of the social contract and the kind of public sphere in the absence of these media? Does it make sense to speak of a social contract in Kachin and Karen communities during the Konbang dynasty (in 1885), during British rule (1886-1947), or at the time of Burmese independence, in 1948?

Maybe this is just nit-picking, asking for discussions of ethno-nationalism, Christianity, the establishment of shared vernaculars, and nation-state institutions, when those are not the main topics of this book. But even leave history aside, and just assume that somehow common languages and publics emerged - then there is still another, more fundamental question: where do we draw the boundaries between the common language used by actors in the public sphere, and the analytical language and the concepts of the observer? This question is particularly urgent when dealing with rebel movements (such as the KNU and the KIO), whose primary and self-declared objective it is is to establish a new social contract. Clearly what Brenner means by a social contract is not just what is stated in the press releases of the KNU and the KIO, or what is said by ordinary people and leaders. Instead the "social contract" of Rebel Politics is a theoretical construct that Brenner uses to describe a complex aggregation of attitudes, norms, and practices. His account brims with epistemological optimism: obviously, there are differences between the ideas of rebels and the ideas of the analyst, these differences can be overcome by generalisation. There are many different forms of exchange and recognition in the Kachin and Karen movements, and different rebels have many different ideas about those things: ultimately, however, all this can be reduced to one essential social process, which Brenner calls the "social contract". On this basis, he then describes a functioning social contract in one place, and disruptions to the same social contract in another (as is done for Mutraw and Hpa'an, two areas governed by the $\mathrm{KNU}$, respectively in chapter three).

The alternative is epistemological pessimism. What if there are forms of exchange and forms of social recognition that contradict the social contract, or social relations that cannot be described as a social contract at all? Scepticism and pessimism might push an analyst further to the edge when it comes to matters of life and death, or rather kinship and violence. The closer we approach those limit cases of human action, the less it makes sense to speak of contractual action. Violent leaders are respected not because they play by the book, but because they are capricious and their violence (or threats of violence) are unacceptable to ordinary people. Some of the leaders Brenner describes, such as a man he calls "General Mutu" in chapter three, are feared precisely because of their erratic behaviour - yet paradoxically, they are also respected, much in the way of a baby-king or a Trump-like figure, who does not play by the rules of the social contract.

Similarly, in regard to kinship, it is at least questionable whether the social contract is the best term to capture what happens between people. What, then, to make of the fact that kinship is central to the rebel politics of highland Myanmar? Many leaders among the Kachin and the Karen are connected to each other and to their business partners by kinship. Imaginaries of paternalist kinship are vital to the emerging ethno-nationalism of these groups. And complicated kinship systems regulate marriages among Karen and Kachin - in fact the political oscillations between egalitarianism and hierarchy among the latter famously were said to be based on the dynamics between wife-givers and wife-takers and the rules of their maternal cross-cousin marriage (Leach 1954). Leach's abstractions had little to do with actual 
Kachin history, but even so, we can safely assume that the decisions Kachin people take when it comes to kinship are more than a simple contract.

Questions such as the cruelty of leaders and the kinship of followers, therefore, stretch a contractual understanding of sovereignty to its limits. Such exceptions might be explained as exceptions that prove the rule, or point to the dilemmas of sovereign immunity: given the difficulty in suing a sovereign, how can you sue a rebel government? Presenting sovereignty as the result of a social contract is only possible if we take a series of correlating assumptions for granted, including the reference to texts and charters, the existence of a public sphere and the common use of reified concepts (specifically the legal person and collective identities).

Generally, these assumptions are common only in the context of mass literacy, schooling, and government bureaucracies: that is, once local actors can build their own republics of paper in which they negotiate collective identities (including nations, states, and civil societies) in relationship to printed texts - more often than not, newpapers. While Rebel Politics has little to say about the history of such paper republics among the Kachin and Karen, it offers a falsifiable theory of the social contract among the armed movements of the KIO and KNO: a theory that is well-crafted, that can be tested, and proven wrong. On this basis, it will be core reading for anyone interested in rebel governance in Myanmar and elsewhere.

\section{References}

Leach, Edmund. 1954. Political Systems of Highland Burma: A Study of Kachin Social Structure. London: Athlone Press.

Lintner, Bertil. 1990. The Rise and Fall of the Communist Party of Burma (CPB). Ithaca, NY: Cornell SEAP.

-1999. Burma in Revolt: Opium and Insurgency since 1948. Chiang Mai: Silkworm Books.

Lintner, Bertil, and Michael Black. 2009. Merchants of Madness: The Methamphetamine Explosion in the Golden Triangle. Chiang Mai: Silkworm Books.

Lukács, Georg. 1971. History and Class Consciousness: Studies in Marxist Dialectics. Cambridge, MA: MIT Press. 